\title{
Velké šelmy pohledem žáků Zš a Sš
}

\author{
Jan Andreska, Martin Mejzr \\ Envigogika 2012/VII/3- Recenzované články/ Reviewed Papers \\ Publikováno/Published 31 12. 2012
}

DOI: http://dx.doi.org/10.14712/18023061.76

\begin{abstract}
Abstrakt:
Vzhledem k občasnému výskytu medvědů a vlků na českém území se stále častěji hovoří o problémech spojených s jejich prítomností. Velká část veřejnosti tyto šelmy stále považuje za nebezpečné, a dokonce si myslí, že člověka považují za potenciální kořist. $\mathrm{Na}$ toto téma byla již provedena řada průzkumů, které to potvrzují, avšak žádný z nich nebyl zaměřen na názory žáků základních a středních škol. Žáci jsou součástí školního vzdělávacího systému a informace ze školní výuky by měly z větší části formovat i jejich názor na velké šelmy. Cílem této práce tedy bylo zjistit postoje žáků základních a studentů středních škol $\mathrm{z}$ různých oblastí České republiky $\mathrm{k}$ vybraným šelmám. Postoje žáků se zjištovaly na základě dotazníkového šetření. Mezi respondenty byli zahrnuti i žáci ze základní školy ve Vysokých Tatrách, tedy z oblasti, kde se všechny velké šelmy vyskytují a nikdy člověkem nebyly vyhubeny. Jak ale ukazují výsledky tohoto šetření, informace žáků o nebezpečnosti šelem jsou zkreslené. Žáci považují velké šelmy za člověka nebezpečné o hodně častěji než dospělí. Více než třetina dotazovaných žáků si myslí, že vlk je agresivní a při každém střetu s člověkem ho může napadnout. Stejného názoru na medvěda je dokonce více než polovina dotazovaných. Výsledky této práce mají poukázat na informovanost žáků o našich šelmách a mohly by být prospěšné $v$ osvětových programech spojených s reintrodukcí velkých šelem zpět do prírody.
\end{abstract}

\section{Klíčová slova:}

Medvěd, vlk, rys, liška, šelmy, nebezpečnost šelem

\begin{abstract}
:
The majority of the public considers these predators to be dangerous and even thinks that they look upon humans as prey. There has been much research carried out on this topic, which this fact confirms, but none of it has focused on the opinions of of primary and secondary school pupils. Students are part of the school educational system and their opinions about large predators are largely formed from the information they receive through school education. The purpose of this assignment was to find out the attitudes of primary and secondary school students from different parts of the Czech Republic towards selected predators. The investigation into student attitudes was based on a survey. The respondents included students from a primary school in the High Tatras Mountains, i.e. an area where many large carnivores are located which have never been eradicated by humans. As the results of the survey show, the information students receive about predator danger is distorted. Students consider large carnivores to be dangerous to humans more often than adults do. More than a third of the surveyed pupils think that the wolf is aggressive and may attack each time it meets a human. More than half are of the same opinion regarding the danger posed by the brown bear. The results of this research
\end{abstract}


may demonstrate the level of information pupils possess regarding large predators and could contribute toward public awareness programs related to the reintroduction of large carnivores back into nature.

\section{Key words:} danger

European brown bear, grey wolf, Eurasian lynx, red fox, carnivores, carnivore 


\section{Úvod}

Ve dvacátém století se na území České republiky postupně vracela řada obratlovců vytlačených ze svého původního areálu člověkem lovcem a zemědělcem. Tyto návraty byly ochranářsky cítící částí veřejnosti vnímány pozitivně, často dokonce jako velmi spektakulární úspěchy aplikované environmentalistiky. Jiná část společnosti ale návrat některých druhů, zejména predátorů, přijala přinejmenším s rozpaky. Tak byl např́klad rybáŕi přijat (respektive zcela nepřijat) návrat kormorána velkého (Andreska, 2012). Široká veřejnost vnímá s rozpaky dynamický růst populace dalšího navrátilce, tedy prasete divokého. Samostatnou kapitolu ve vnímání zmíněných návratů tvoří návrat velkých šelem, tedy medvěda, vlka a rysa (Andreska, 2010). Zde je averze často velmi intenzivní, $\checkmark$ regionech, kde se tyto šelmy vyskytují, se proti jejich př́tomnosti staví zejména myslivci. Negativně jejich př́tomnost vnímají také chovatelé ovcí, včelaři, kupodivu často také turisté. To podněcuje dílem strach z prítomnosti šelem, dílem skutečné nebo domnělé škody, které šelmy působí.

Podstatné směrem do budoucnosti je přijetí velkých šelem nejmladší generací. To jednoznačně souvisí $s$ výchovou, at' už v rodině, nebo $s$ environmentální výchovou ve škole. Zkoumáním postojů žákư se zabývá předložená práce. Její jádro bylo původně obhájeno jako diplomová práce (Porovnání postojů žáků ZŠ a SŠ k velkým šelmám, zejména pak k vlku obecnému (Canis lupus) a psu domácímu (Canis lupus familiaris)), přepracováním spočívajícím $v$ redukci, doplnění a interpretaci získaných údajů vznikla tato studie.

\section{Materiál a metodika}

Nástrojem zjištóování názorů žáků byl nestandardizovaný původní dotazník, který obsahoval celkem 13 otázek, přičemž ke zjištění postojů žáků k velkým šelmám sloužilo 6 otázek, zbylé otázky zjištovaly informovanost žákủ o původu psa domácího.

\section{Výběr a charakteristika respondentů}

Dotazníky byly cíleny na žáky osmých a devátých tříd základních škol a na studenty prim a sekund šestiletých gymnázií. Do tříd byly distribuovány po předchozí domluvě $\mathrm{s}$ řediteli škol a s učiteli. Oblasti výzkumu byly vybrány záměrně, a to tak, aby obsahovaly lokality jak s výskytem velkých šelem, tak i místa, kde se tito savci minimálně 250 let nevyskytují. Dotazováni byli žáci v Praze, ve středních Čechách, Moravskoslezských Beskydech, na Šumavě a ve Vysokých Tatrách. Výsledky byly porovnány mezi jednotlivými oblastmi, podle věku žáků, jejich pohlaví i souhrnně. Sběr dat probíhal v průběhu listopadu a prosince 2011. Celkem bylo osloveno 366 žáků a studentů. Po vytř́ídění neplatně vyplněných dotazníků jich zbylo 348. Poměr dotazovaných chlapců a dívek byl vyrovnaný, 170 : 178. z osmých ročníků ZŠ odpovědělo 117 , z devátých ročníků 115 , z prim šestiletého gymnázia 60 a ze sekund 56 žáků.

Tab. 1: Rozdělení získaného souboru respondentů podle pohlaví a školního ročníku, $\checkmark$ procentech.

\begin{tabular}{|l|l|l|}
\hline ŠKOLNÍ ROČNÍK & CHLAPCI & DÍVKY \\
\hline 8. ročník ZŠ & 15,80 & 17,82 \\
\hline 9. ročník ZŠ & 18,97 & 14,08 \\
\hline prima šestiletého gymnázia & 7,47 & 9,77 \\
\hline
\end{tabular}




\begin{tabular}{|l|l|l|}
\hline sekunda šestiletého gymnázia & 6,61 & 9,48 \\
\hline celkem & $\mathbf{4 8 , 8 5}$ & $\mathbf{5 1 , 1 5}$ \\
\hline
\end{tabular}

V dotazníku žáci odpovídali mimo jiné na tyto otázky:

- Z Zda někdy viděli v přírodě některou z velkých šelem a kde to bylo.

- Zda se domnívají, že jsou vybrané šelmy (liška, medvěd, rys, vlk, pes) člověku nebezpečné a proč.

- Jaká je podle nich funkce vlka v ekosystému.

- Zda mohou v české (respektive slovenské) př́rodě potkat vlka.

\section{Výsledky}

\section{Pozorování velkých šelem}

Žáci jako nejčastěji zpozorovanou velkou šelmu uvedli rysa ostrovida, toho vidělo téměř $15 \%$ z nich. Naopak nejméně často žáci ve volné přírodě zahlédli medvěda (10 \%). VIka zpozorovalo $12 \%$ dotazovaných žáků.

Při porovnání vzorků z různých oblastí výzkumu vyplývá, že medvěda nejčastěji pozorovali žáci z Vysokých Tater. Medvěda vidělo 40 \% z nich. Nejnižší počet pozorování medvěda uváděli šumavští žáci (3\%). Ti naopak nejčastěji uváděli, že zpozorovali rysa. Oproti tomu nejméně často rysa spatřili středočeští žáci ( $8 \%$ z nich). Nejčastější pozorování vlků uváděli žáci ze Slovenska, nejnižší četnost spatření vlka je u šumavských žáků. Viz Tab. 2:

Tab. 2: Počty pozorování velkých šelem podle jednotlivých oblastí, v procentech.

\begin{tabular}{|l|l|l|l|l|l|l|}
\hline pozorování velkých šelem v přírodě Šumava & Vys. Tatry & Praha & Beskydy & stř. Čechy \\
\hline pozorování medvěda & 3 & 40 & 8 & 5 & 5 \\
\hline pozorování rysa & 21 & 15 & 16 & 10 & 8 \\
\hline pozorování vlka & 5 & 28 & 9 & 15 & 8 \\
\hline
\end{tabular}

\section{Nebezpečnost šelem}

Svůj postoj k nebezpečnosti šelem vyjádřil každý z 348 žáků. v dotazníku žáci odpovídali, zda považují vybrané šelmy (liška, medvěd, rys, vlk, pes) za člověku nebezpečné, či nikoliv. Dále uváděli př́činy jejich nebezpečnosti. Za nejnebezpečnější šelmu považují žáci medvěda, toho jako nebezpečného uvedlo $92 \%$ z nich. Naopak za člověku nejméně nebezpečnou šelmu žáci považují rysa. 


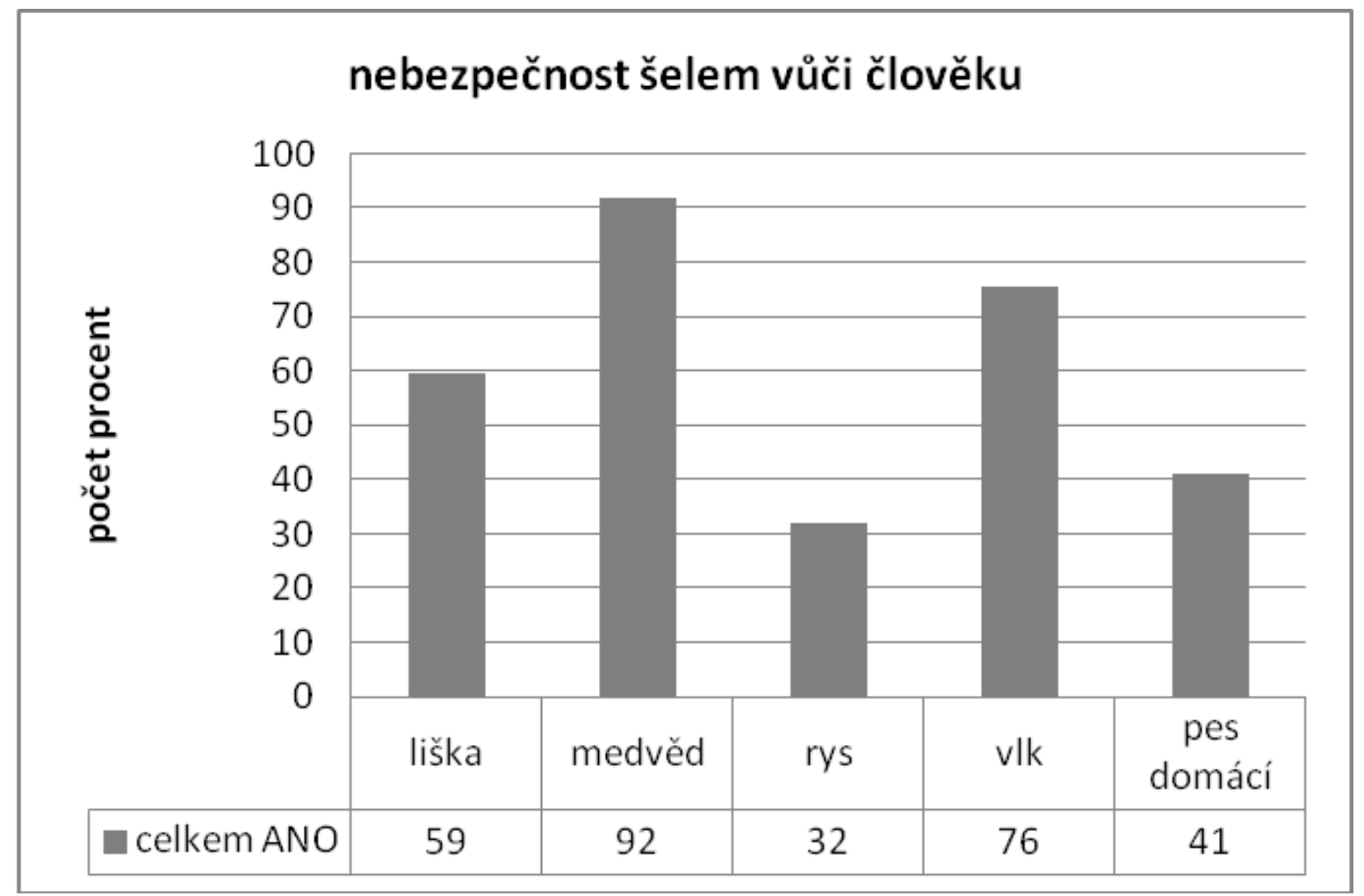

Graf 1: Počet žáků, kteří se domnívají, že je daná šelma člověku nebezpečná, $\mathrm{v}$ procentech.

Patrné rozdíly vyvstaly při porovnání odpovědí žáků mezi jednotlivými oblastmi. Žáci ze všech oblastí shodně nejčastěji uváděli medvěda jako lidem nebezpečného. Největší rozpory v odpovědích žáků nalezneme u rysa ostrovida. Toho za nebezpečného nejčastěji považovali žáci z Vysokých Tater (40\%), naopak nejméně často ho jako nebezpečného vnímají šumavští (29 \%) a beskydští studenti (25\%). Ve všech těchto lokalitách rys ostrovid žije, tudíž postoje žáků jsou nezávislé na výskytu této šelmy v regionu. Také vlka považují slovenští žáci nejčastěji za nebezpečného ( $85 \%$ ), z beskydských studentů ho za potenciálně nebezpečného považuje jen $66 \%$ z nich.

Tab. 3: Porovnání odpovědí týkajících se nebezpečnosti vybraných šelem, podle oblastí výzkumu, v procentech.

\begin{tabular}{|l|l|l|l|l|l||}
\hline $\begin{array}{l}\text { nebezpečnost } \\
\text { šelem }\end{array}$ & $\begin{array}{l}\text { ŠUMAVA- } \\
\text { ANO }\end{array}$ & $\begin{array}{l}\text { VYS. } \\
\text { ANO }\end{array}$ & $\begin{array}{l}\text { TATRY- } \\
\text { ANO }\end{array}$ & $\begin{array}{l}\text { BESKYDY- } \\
\text { ANO }\end{array}$ & $\begin{array}{l}\text { STŘ. ČECHY- } \\
\text { ANO }\end{array}$ \\
\hline liška & 60 & 53 & 58 & 61 & 66 \\
\hline medvěd & 94 & 91 & 96 & 85 & 89 \\
\hline rys & 29 & 40 & 31 & 25 & 38 \\
\hline vlk & 78 & 85 & 74 & 66 & 79 \\
\hline
\end{tabular}




\begin{tabular}{|l|l|l|l|l|l|l|}
\hline pes domácí & 43 & 43 & 41 & 36 & 43 \\
\hline
\end{tabular}

\section{Př́íčiny nebezpečnosti šelem}

U př́činy nebezpečnosti šelem měli žáci uvést, z jakého důvodu označili danou šelmu za člověku nebezpečnou. Jednalo se tedy o otevřenou položku. Výsledky jsou soupisem četnosti jednotlivých odpovědí žáků.

K odpovědi $A N O$, liška je člověku nebezpečná se bliže vyjádřilo 203 respondentů. Téměř devadesát procent žáků, kteří se domnívají, že jsou lišky nebezpečné, uvedlo jako příčinu této nebezpečnosti riziko nákazy vzteklinou. Necelých $5 \%$ žáků si myslí, že lišky jsou agresivní, a tudíž vždy nebezpečné. Necelá 4 \% žáků nedokázala své tvrzení o nebezpečnosti konkrétněji popsat. Mezi odpověd'mi se dále vyskytlo, že lišky jsou nebezpečné při obraně sebe či svých mlád’at nebo po vyprovokování člověkem.

Tab. 4: Důvody nebezpečnosti lišky pro člověka, v procentech. ${ }^{1}$

\begin{tabular}{|l|l|}
\hline NEBEZPEČNOST LIŠKY & $\begin{array}{l}\text { Celkem } \\
\text { (n = 203) }\end{array}$ \\
\hline vzteklina & 89,7 \\
\hline nebezpečné vždy, agresivní & 4,9 \\
\hline nevím & 3,9 \\
\hline obrana & 0,5 \\
\hline po podráždění & 0,5 \\
\hline ochrana mlád'at & 0,5 \\
\hline
\end{tabular}

Odpovědi žáků k nebezpečnosti medvěda byly seskupeny do kategorií podle výzkumu Wechselbergerové et al. (2005). Ze 310 žáků, kteří považují medvěda za nebezpečného, se $60 \%$ z nich domnívá, že je nebezpečný vždy, a to z důvodu agresivity. Desetina jich nebyla schopna nebezpečnost medvěda bliže odůvodnit. $9 \%$ žáků se domnívá, že nebezpečné jsou zejména medvědice s mlád'aty. Mezi další př́rčiny nebezpečnosti medvěda patří podle žáků: vyprovokovaný či hladový medvěd, synantropní nebo také takzvaný „kontejnerový" medvěd, vyrušený a překvapený medvěd nebo jedinec nakažený vzteklinou.

$1 v$ tabulce přícin nebezpečnosti rysa je $z$ důvodu zachování některých odpovědí zaokrouhleno na 1 desetinné místo. 
Důvody nebezpečnosti medvěda pro člověka, v procentech.

\begin{tabular}{|c|c|c|}
\hline NEBEZPEČNOST MEDVĚDA & Celkem (n & $n=310)$ \\
\hline 1. vždy je nebezpečný & & 60 \\
\hline 2. nevím & & 10 \\
\hline 3. samice s mlád'aty & & 9 \\
\hline 4. po vyprovokování medvě & & 5 \\
\hline 5. hladový medvěd & & 4 \\
\hline 6. v okolí lidských obydlí (p & elnice) & 3 \\
\hline 7. v případě narušení terito & medvěda & 3 \\
\hline 8. nevyzpytatelný & & 2 \\
\hline 9. veliký & & 2 \\
\hline 10. překvapený medvěd & & 1 \\
\hline 11. medvěd se cítí ohrožen & & 1 \\
\hline 12. zraněný nebo nemocný & edvěd & 0 \\
\hline 13. vzteklina & & 0 \\
\hline 14. po zimním spánku & & 0 \\
\hline
\end{tabular}

Zajímavé však bylo porovnání odpovědí podle regionu. $24 \%$ slovenských žáků uvedlo, že nebezpečná mưže být medvědice s mlád'aty, kdežto žáci z ostatních lokalit tuto možnost uváděli minimálně - vždy do $10 \%$ odpovědí. Také ostatní odpovědi žáků z Vysokých Tater, tedy oblasti, kde se medvědi celkem hojně vyskytují, jsou relevantnější než tvrzení dotazovaných z jiných oblastí. Tito žáci nikdy nenapsali "nevím" a ani neuvedli, že medvěd je veliký a silný nebo že případně může být nebezpečným medvěd, který je zraněný či nemocný. Také 10 \% odpovědí týkajících se nebezpečnosti tzv. synantropních medvědů zcela jistě vypovídá o jejich zkušenostech s těmito medvědy.

Tab. 5: Důvody nebezpečnosti medvěda podle žáků z jednotlivých oblastí, $\mathrm{v}$ procentech.

\begin{tabular}{|l|l|l|l|l|l|}
\hline $\begin{array}{l}\text { NEBEZPEČNOST } \\
\text { MEDVĚdA }\end{array}$ & $\begin{array}{l}\text { Vysoké } \\
\text { Tatry } \\
\mathbf{4 2})\end{array}$ & $\begin{array}{l}\text { Stř. Čechy } \\
(\mathbf{n = 5 3})\end{array}$ & $\begin{array}{l}\text { Šumava (n } \\
=\mathbf{5 7})\end{array}$ & $\begin{array}{l}\text { Beskydy (n } \\
=\mathbf{5 1})\end{array}$ & $\begin{array}{l}\text { Praha (n } \\
=\mathbf{1 0 7})\end{array}$ \\
\hline 1. vždy je nebezpečný & 55 & 64 & 59 & 58 \\
\hline
\end{tabular}




\begin{tabular}{|c|c|c|c|c|c|}
\hline 2. nevím & 0 & 6 & 7 & 22 & 11 \\
\hline $\begin{array}{l}\text { 3. po vyprovokování } \\
\text { medvěda }\end{array}$ & 0 & 6 & 2 & 0 & 10 \\
\hline 4. samice s mlád'aty & 24 & 6 & 4 & 6 & 8 \\
\hline 5. hladový medvěd & 5 & 2 & 4 & 0 & 7 \\
\hline $\begin{array}{l}\text { 6. v okolí lidských } \\
\text { obydlí (popelnice) }\end{array}$ & 10 & 2 & 4 & 2 & 2 \\
\hline 7. nevyzpytatelný & 0 & 4 & 2 & 4 & 2 \\
\hline $\begin{array}{l}\text { 8. v případě narušení } \\
\text { teritoria medvěda }\end{array}$ & 2 & 8 & 0 & 6 & 1 \\
\hline 9. vzteklina & 0 & 0 & 0 & 0 & 1 \\
\hline $\begin{array}{l}\text { 10. zraněný } \\
\text { nemocný medvěd }\end{array}$ & 0 & 0 & 0 & 2 & 0 \\
\hline $\begin{array}{l}11 . \\
\text { medvěd } \quad \text { překvapený }\end{array}$ & 5 & 2 & 0 & 0 & 0 \\
\hline $\begin{array}{l}\text { 12. medvěd se cítí } \\
\text { ohrožený }\end{array}$ & 0 & 0 & 4 & 0 & 0 \\
\hline 13. veliký & 0 & 0 & 11 & 0 & 0 \\
\hline 14. po zimním spánku & 0 & 2 & 0 & 0 & 0 \\
\hline
\end{tabular}

Svůj názor na nebezpečnost vlka konkrétněji popsalo 215 žáků a jejich odpovědi byly řazeny do kategorií podle dotazníku od Wechselbergerové et al. (2005). Že jsou vlci agresivní a člověku vždy nebezpeční, se domnívá $60 \%$ žáků. Stejná část dotázaných ( 9 $\%)$ uvedla, že za nebezpečného můžeme považovat hladového nebo vzteklinou nakaženého vlka. Téměř $8 \%$ žáků si myslí, že vlci jsou nebezpeční jen tehdy, pokud jsou ve smečce. Jako další príčiny nebezpečnosti vlkủ žáci uvedli pocit ohrožení, ochranu mlád'at nebo narušení teritoria.

Tab. 6: Př́činy nebezpečnosti vlka podle všech respondentů, v procentech.

\section{NEBEZPEČNOST VLKA \\ Celkem $(n=215)$}

1. nebezpeční vždy, agresivní 60

2. hladový vlk

9 


\begin{tabular}{|l|l|l|}
\hline 3. vzteklina & 9 \\
\hline 4. nevím & 9 \\
\hline 5. ve smečce & 8 \\
\hline 6. v pocitu ohrožení & 1 \\
\hline 7. ochrana mlád'at & 1 \\
\hline 8. narušení teritoria & \\
\hline 9. v zimě / během kruté zimy & 0 \\
\hline
\end{tabular}

Také u příčin nebezpečnosti vlka vykazovaly odpovědi žáků z Vysokých Tater menší variabilitu a měly vždy faktickou podobu. Žádný z nich neuvedl jako důvod nebezpečnosti největší psovité šelmy pocit ohrožení, ochranu mlád’at, krutou zimu či narušení teritoria a vždy popsali konkrétní příčinu. Naopak čtvrtina beskydských a desetina šumavských žáků nedokázala uvést faktickou př́činu nebezpečnosti vlků vưči člověku.

Tab. 7: Příčiny nebezpečnosti vlka podle žáků z jednotlivých oblastí, v procentech.

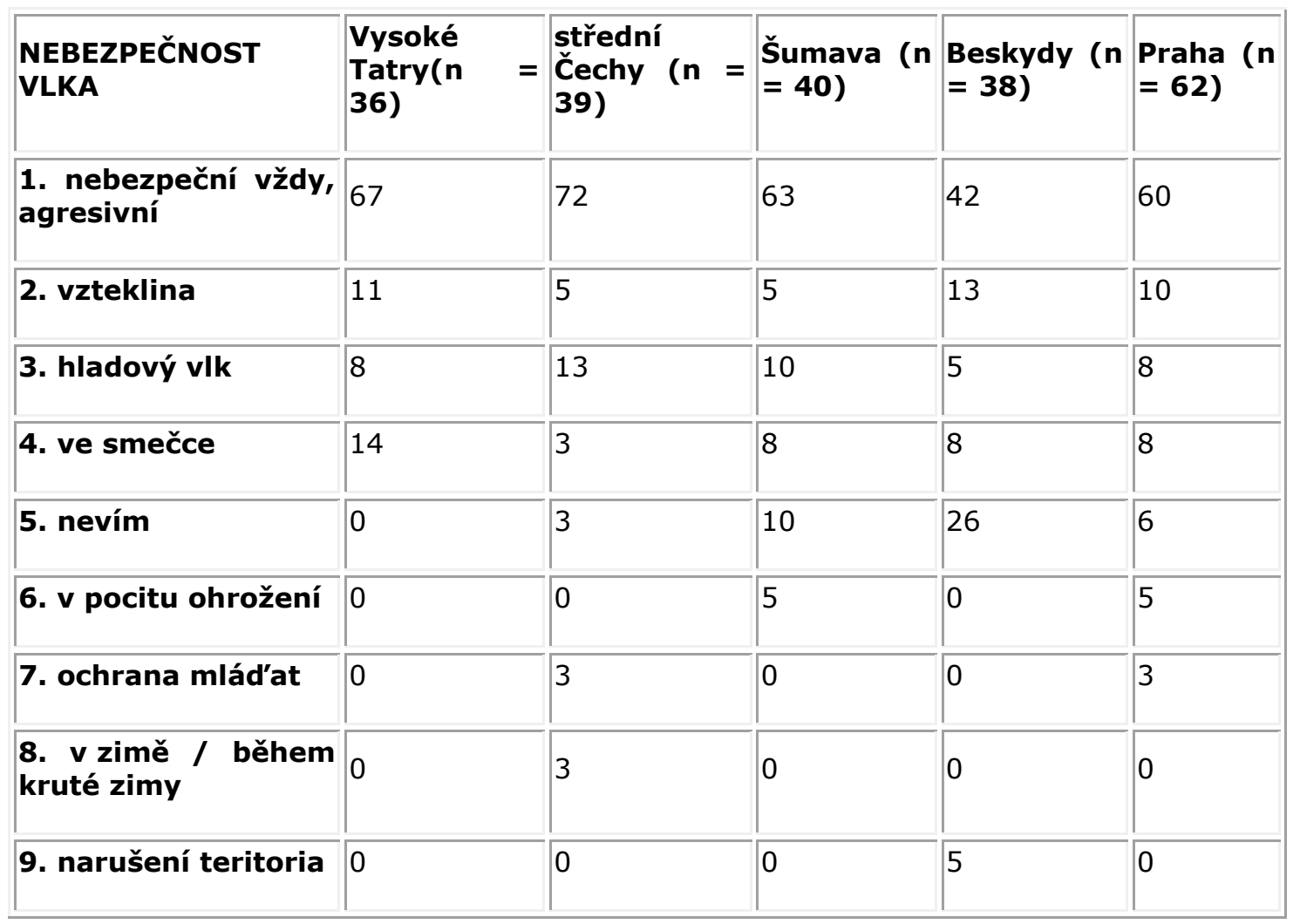


Příčiny nebezpečnosti rysa ostrovida byly rovněž kategorizovány podle Wechselbergerové et al. (2005) a blíže je vysvětlilo 97 žáků (tedy ti z respondentů, kteří jsou o jeho nebezpečnosti přesvědčeni). 52 \% z nich se domnívá, že rys je agresivní a vždy nebezpečný, 24 \% pak nedokázalo své tvrzení o nebezpečnosti konkrétně popsat. 9 \% žáků si myslí, že rys na člověka může zaútočit po vyprovokování a 6 \% dotazovaných je přesvědčeno, že napadnout člověka může pouze jedinec nakažený vzteklinou. Jako další možné příčiny nebezpečnosti rysa žáci uváděli matku bránící mlád'ata, nedostatek potravy, narušení teritoria či vlastní obranu.

Tab. 8: Př́činy nebezpečnosti rysa podle všech respondentů, v procentech.

\begin{tabular}{|c|c|c|}
\hline NEBEZPEČNOST RYSA & $\mathbf{C}$ & elkem ( $n=97)$ \\
\hline 1. vždy je agresivní, nebezpečný & 52 & \\
\hline 2. nevím & 24 & \\
\hline 3. po vyprovokování & 9 & \\
\hline 4. vzteklina & 6 & \\
\hline 5. matka chránící mlád’ata & 2 & \\
\hline 6. pokud se cítí ohrožený, v obraně & 2 & \\
\hline 7. pokud není dostatek potravy pro rysa & 2 & \\
\hline 8. pokud má hlad & 1 & \\
\hline 9. překvapený rys & 1 & \\
\hline 10. narušení teritoria & 1 & \\
\hline
\end{tabular}

Při porovnání příčin nebezpečnosti šelem vykazují názory žáků z různých lokalit (konkrétně v případě rysa) největší rozdíly. 82 \% slovenských žáků se domnívá, že rys je vždy nebezpečný a agresivní, oproti tomu stejného názoru není více jak $40 \%$ šumavských, beskydských ani pražských žáků. Ti ale zase nejčastěji nedokázali svoji odpověd' blíže popsat. 26 \% středočeských žáků se domnívá, že rys na člověka může zaútočit po vyprovokování, obdobný postoj ale z jiných oblastí nesdílí nikdy více než 7 \% žáků.

Tab. 9: Příčiny nebezpečnosti rysa podle žáků z jednotlivých oblastí, v procentech.

\begin{tabular}{|c|c|c|c|c|c|}
\hline NEBEZPEČNOST RYSA & $\begin{array}{l}\text { Vysoké } \\
\text { Tatry }(\mathrm{n}= \\
17)\end{array}$ & $\begin{array}{l}\text { střední } \\
\text { Čechy }(n= \\
19)\end{array}$ & $\begin{array}{l}\text { Šumava (n } \\
=15)\end{array}$ & $\begin{array}{l}\text { Beskydy (n } \\
=13)\end{array}$ & $\begin{array}{l}\text { Praha (n } \\
=33)\end{array}$ \\
\hline
\end{tabular}




\begin{tabular}{|c|c|c|c|c|c|}
\hline $\begin{array}{l}\text { 1. vždy je agresivní, } \\
\text { nebezpečný }\end{array}$ & 82 & 63 & 40 & 38 & 39 \\
\hline 2. nevím & 0 & 5 & 40 & 31 & 36 \\
\hline 3. vzteklina & 0 & 0 & 0 & 8 & 15 \\
\hline 4. po vyprovokování & 6 & 26 & 7 & 0 & 6 \\
\hline $\begin{array}{l}\text { 5. pokud se cítí } \\
\text { ohrožený, v obraně }\end{array}$ & 0 & 0 & 0 & 8 & 3 \\
\hline 6. pokud má hlad & 6 & 0 & 0 & 0 & 0 \\
\hline $\begin{array}{l}\text { 7. matka chránící } \\
\text { mlád'ata }\end{array}$ & 6 & 5 & 0 & 0 & 0 \\
\hline 8. překvapený rys & 0 & 0 & 0 & 8 & 0 \\
\hline 9. narušení teritoria & 0 & 0 & 0 & 8 & 0 \\
\hline $\begin{array}{l}\text { 10. pokud není dostatek } \\
\text { potravy pro rysa }\end{array}$ & 0 & 0 & 13 & 0 & 0 \\
\hline
\end{tabular}

Své názory na původ nebezpečnosti psa domácí blíže popsalo 131 žáků. Položky, do kterých byly odpovědi kategorizovány, odpovídaji vlastním odpovědím žáků a také částečně korespondují s kategoriemi u vlka. $31 \%$ žáků, kteří se domnívají, že je pes člověku nebezpečný, spojuje tuto nebezpečnost s nákazou vztekliny. Stejná část dotazovaných - $27 \%$ - je názoru, že jsou psi přirozeně agresivní nebo že záleží na výchově a výcviku psa. Žáci za riskantní dále považují setkání s vyprovokovaným nebo své území hájícím psem. Špatného majitele jako pưvod potenciálního nebezpečí střetu člověka a psa vnímá pouze zlomek dotázaných.

Tab. 10: Důvody nebezpečnosti psa domácího podle všech respondentů, $\checkmark$ procentech.

\begin{tabular}{|l|l|}
\hline NEBEZPEČNOST PSA & Celkem $(\mathbf{n}=\mathbf{1 3 1})$ \\
\hline 1. vzteklina & 31 \\
\hline 2. nebezpeční vždy, agresivní & 27 \\
\hline 3. záleží na výcviku a výchově & 27 \\
\hline 4. po vyprovokování & 8 \\
\hline 5. obrana teritoria & 2 \\
\hline
\end{tabular}




\begin{tabular}{|l|l|}
\hline 6. nevím & 2 \\
\hline 7. kvůli potravě, hlad & 2 \\
\hline 8. jak kteří psi & 1 \\
\hline 9. špatný majitel & 1 \\
\hline
\end{tabular}

Žáci z Tater se daleko častěji než žáci z jiných oblastí domnívají, že nebezpečnými jsou zejména vzteklinou nakažení psi. Beskydští studenti si nejčastěji ze všech myslí, že záleží na člověku, jak psa vychová a vycvičí, a tím minimalizuje riziko jejich útoků na lidi.

Tab. 11: Příčiny nebezpečnosti psa podle žáků z jednotlivých oblastí, v procentech.

\begin{tabular}{|c|c|c|c|c|c|}
\hline NEBEZPEČNOST PSA & $\begin{array}{l}\text { Vysoké Tatry }(\mathrm{n}= \\
\text { 20) }\end{array}$ & $\begin{array}{l}\text { střední Čechy }(\mathrm{n}= \\
\text { 25) }\end{array}$ & $\begin{array}{l}\text { Šumava }(\mathrm{n}= \\
26)\end{array}$ & $\begin{array}{l}\text { Beskydy }(\mathrm{n}= \\
20)\end{array}$ & $\begin{array}{l}\text { Praha }(n= \\
40)\end{array}$ \\
\hline $\begin{array}{l}\text { 1. nebezpeční vždy, } \\
\text { agresivní }\end{array}$ & 10 & 36 & 23 & 30 & 28 \\
\hline $\begin{array}{l}\text { 2. záleží na výcviku } \\
\text { a výchově }\end{array}$ & 35 & 24 & 12 & 45 & 25 \\
\hline 3. vzteklina & 50 & 32 & 38 & 20 & 20 \\
\hline 4. po vyprovokování & 0 & 4 & 23 & 0 & 10 \\
\hline 5. nevím & 0 & 0 & 0 & 0 & 8 \\
\hline 6. kvůli potravě, hlad & 0 & 0 & 0 & 0 & 6 \\
\hline 7. špatný majitel & 0 & 0 & 0 & 0 & 3 \\
\hline 8. obrana teritoria & 5 & 4 & 0 & 5 & 0 \\
\hline 9. jak kteří psi (povaha psa) & 0 & 0 & 4 & 0 & 0 \\
\hline
\end{tabular}

\section{Funkce vlka v prírirodě}

U otázky týkající se prospěšnosti vlků v přírodě měli žáci na výběr ze čtyř možností: "Vlk je v přírodě prospěšný", "vlk prírodě škodí", "vlk nemá pro prírodu žádný význam" a "nevím". $51 \%$ dotázaných $(n=348)$ je názoru, že vlci jsou $v$ prírodě užiteční a naopak pouze $4 \%$ žáků si myslí, že volný výskyt vlků prírodě škodí. $34 \%$ žáků pak nevědělo, jak odpovědět. 


\section{funkce vlka v přírodě}

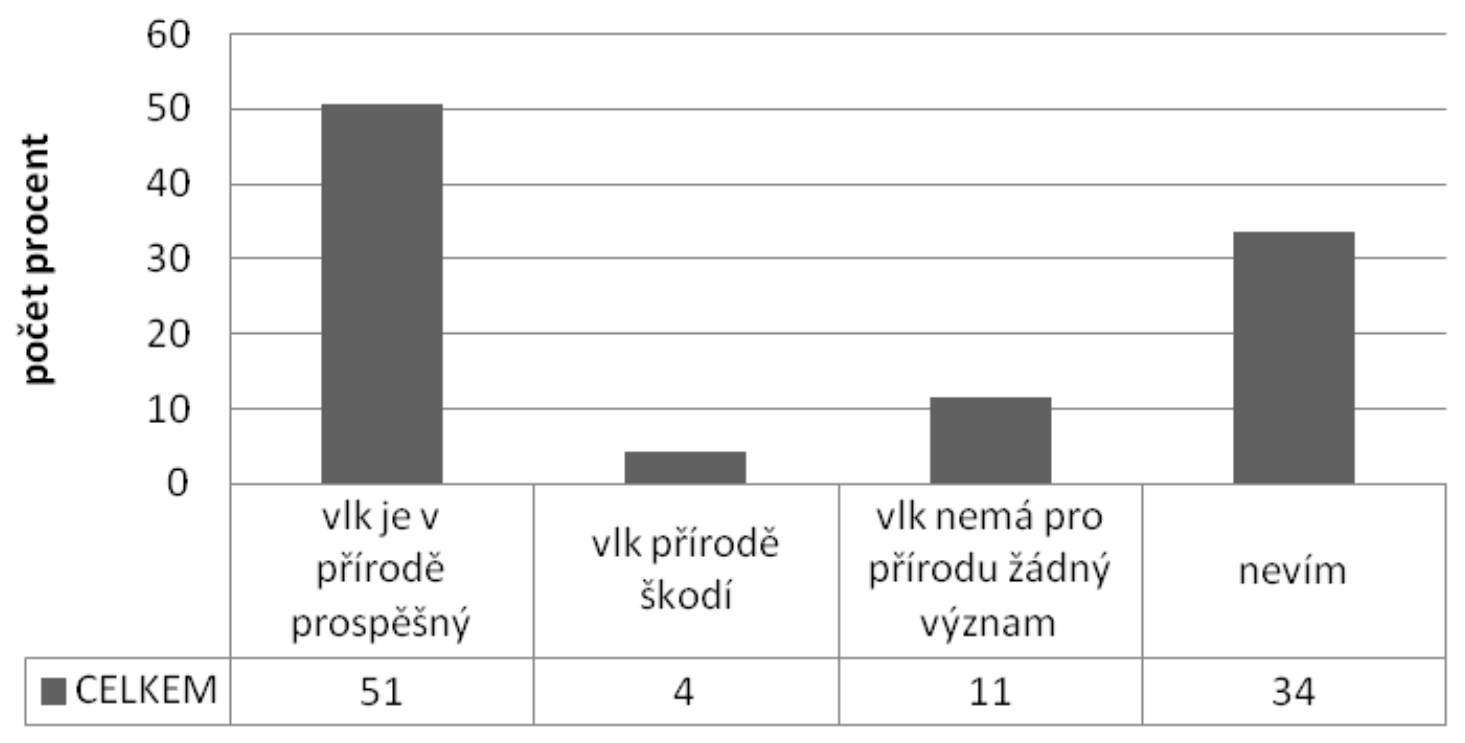

Graf 2: Názor všech respondentů na funkci vlka v přírodě, v procentech.

Nejvíce žáků, kteří jsou o prospěšnosti vlka v přírodě přesvědčeni je z Prahy, naopak nejméně z Vysokých Tater, Šumavy a Beskyd, tedy oblastí, kdy vici žijí nebo se v poměrně nedávné době vyskytovali. Respondenti z horských oblastí také nejčastěji odpovídali "nevím". 


\section{Funkce vlka v prírodě}

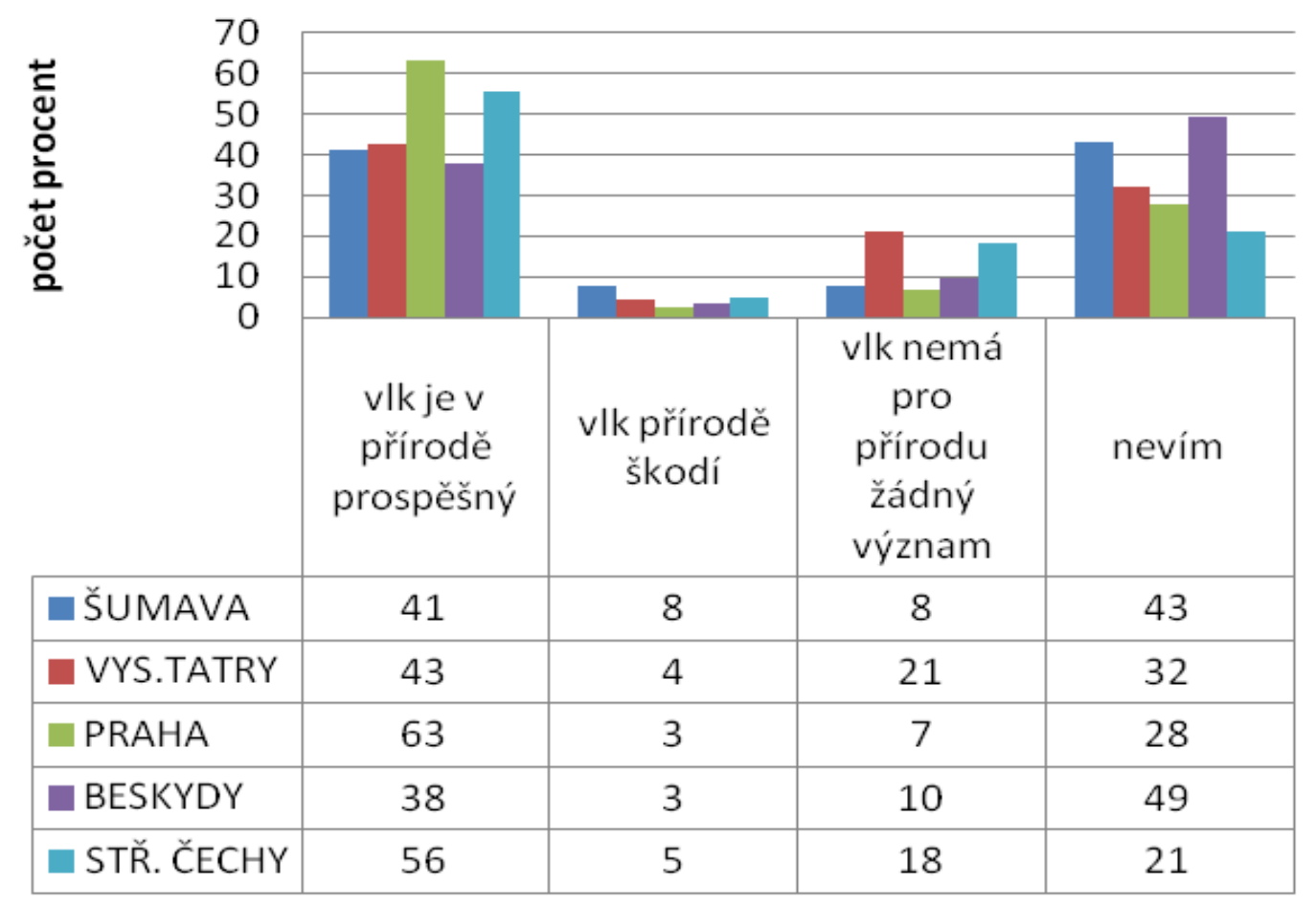

Graf 3: Grafické znázornění názorů žáků z jednotlivých oblastí výzkum na funkci vlka v ekosystému, v procentech.

Výskyt vlků na území České a Slovenské republiky

K otázce výskytu vlků na českém území se vyjádřilo 301 žáků českých a 47 žáků slovenských škol. $70 \%$ žáků českých základních a středních škol se domnívá, že na našem území vlci žijí. Pouze $1 \%$ žáků nedokázalo na tuto otázku odpovědět.

Tab. 12: Odpovědi žáků na otázku, zda v př́rodě ( $v$ jejich zemi) Ize potkat vlka, $\checkmark$ procentech.

\begin{tabular}{|c|c|c|c|c|c|}
\hline $\begin{array}{lr}\text { MŮŽETE } & \text { NĚKDE } \\
\text { v ČR/SR } & \text { POTKAT } \\
\text { VLKA? } & \end{array}$ & $\begin{array}{l}\text { ŠUMAVA (n } \\
=63)\end{array}$ & $\begin{array}{l}\text { VYS. } \\
\text { TATRY }(n= \\
47)\end{array}$ & $\begin{array}{l}\text { PRAHA (n } \\
=116)\end{array}$ & $\begin{array}{l}\text { BESKYDY ( } \\
=61)\end{array}$ & $\begin{array}{l}\text { STŘ. } \\
\text { ČECHY }(n= \\
61)\end{array}$ \\
\hline Ano, mohu & 52 & 98 & 67 & 84 & 77 \\
\hline Ne, nemohu & 48 & 0 & 3 & 16 & 23 \\
\hline Nevím & 0 & 2 & 3 & 0 & 0 \\
\hline
\end{tabular}


Tab. 13: Odpovědi českých žáků na otázku, zda v české př́rodě lze potkat vlka, $\checkmark$ procentech.

\begin{tabular}{|l|l|}
\hline MƯŽETE NĚKDE $v$ ČR POTKAT VLKA? & Čeští žáci celkem \\
\hline Ano, mohu & 70 \\
\hline Ne, nemohu & 29 \\
\hline Nevím & 1 \\
\hline
\end{tabular}

Ze slovenských respondentů si drtivá většina žáků ( $98 \%$ ) je vědoma výskytu vlků na jejich území. Pouze $2 \%$ dotázaných nedokázalo odpovědět a žádný z žáků neodpověděl, že na Slovensku vlci nežijí.

\section{Diskuse}

Z výše uvedeného je patrné, že žáci mají o nebezpečnosti šelem a jejím původu často zkreslené představy. Zčásti se potvrdily předpoklady, že se názory žáků z oblastí, kde se vyskytují velké šelmy, budou lišit od těch žáků, kteří žijí v oblastech, kde se žádná $z$ velkých šelem již po dlouhou dobu nevyskytuje. Naopak je potěšující názor žáků na funkci vlka $v$ ekosystému. To, že jej za prospěšného považuje polovina $z$ nich a pouze $4 \%$ se jich domnívá, že vlk $v$ prírodě škodí, je pozitivní. v osvětových programech a programech zaměřených na návrat vlků na české území je sice třeba změnit názor třetiny žáků, kteří o prospěšnosti vlka stále nemají jasno, ale i tak je to př́slib do budoucna.

Za zajímavé Ize považovat poměrně častá pozorování velkých šelem žáky, a to zejména u žáků žijících mimo oblasti jejich výskytu. Tito žáci ale jako lokality pozorování velkých šelem uváděli Vysoké Tatry, dále pak národní parky ve Spojených státech a $v$ Kanadě. Také vysoký počet setkání šumavských žáků s rysem je překvapivý vzhledem $\mathrm{k}$ plachosti této šelmy. Rovněž u pozorování vlka $v$ př́rodě žáci uváděli oblasti, kde vlci žijí. Není však vyloučené, a vzhledem k vysokému počtu těchto setkání i dost pravděpodobné, že se $v$ některých prípadech jednalo o velké, pravděpodobně ovčácké psy, které žáci zaměnili s vlky.

Zjištění, že žáci z uvedených šelem považují právě medvěda nejčastěji za nebezpečného, není vzhledem ke známým př́padům napadení člověka touto šelmou př́liš překvapivé. Zajímavé, leč v tomto případě správné, je zjištění, že žáci za nebezpečnější považují domestikované domácí zviŕe (psa domácího) než divokou šelmu (rys ostrovid). Zde se jejich názor mohl formovat na základě konkrétních zkušeností či z doslechu od známých, nebo $\mathrm{z}$ informací $\mathrm{v}$ médiích, ve kterých se daleko častěji uvádějí př́ípady napadení člověka psem než rysem, který na člověka neútočí.

Výzkum dále poukázal na fakt, že žáci z Moravskoslezských Beskyd považují $v$ porovnání $s$ žáky $z$ ostatních oblastí velké šelmy méně často za nebezpečné. Jedním $z$ faktorů tohoto jevu může být činnost osvětových programů, které $v$ této oblasti $z$ důvodu pokusů navrátit velké šelmy na toto území fungují. Naopak žáci z Vysokých Tater tyto šelmy považují nejčastěji za nebezpečné. Výjimku tvoří pouze liška obecná, kterou minimum tamních žáků považuje za rizikovou. Pravděpodobně je tomu tak kvưli trvalému výskytu všech tři velkých šelem v Tatrách.

Při srovnání zjištění s jinými obdobně zaměřenými zahraničními výzkumy je zřejmé, že výsledky se vzájemně př́liš neliší. Také norská (Røskaft et al., 2007) i finská veřejnost 
(Liukkonen et al., 2009) považuje z velkých šelem rysa za nejméně nebezpečného. Podle slovenských výzkumů veřejného mínění tamní obyvatelstvo považuje medvědy a vlky za nejnebezpečnější šelmy (Užík \& Adamcová-Kocianová (2007); Wechselbergerová et al., 2005). Za riskantnější pak ale považují setkání s rysem než s liškou, čímž se liší od výsledků našeho výzkumu. Velké rozdíly přineslo srovnání názorů českých a slovenských žáků s estonskými (Randveer, 2001). Z našich žáků vlka jako nebezpečného vnímají 3 ze 4, z estonských pak pouze 42, 70 \%. Také výsledky výzkumu zaměřeného na postoje francouzských obyvatel k velkým šelmám přinášejí odlišné údaje (Bath, 2000). Medvěda sice považují za nejnebezpečnějšího, na druhém místě se ale před vlkem $v$ nebezpečnosti umístil rys ostrovid.

Při srovnání názorů beskydských žáků s názory tamního, převážně zletilého, obyvatelstva (Machalová, 2011) na škodlivost vlků v ekosystému je potěšující, že pouze okolo $3 \%$ žáků proti necelé třetině dospělých vlky tak vnímají. Také mládeže, která si myslí, že vlk nemá $v$ přírodě žádný význam, je podstatně méně než dospělých. Konkrétně každý desátý žák zastává tento názor, kdežto z dospělých každý pátý.

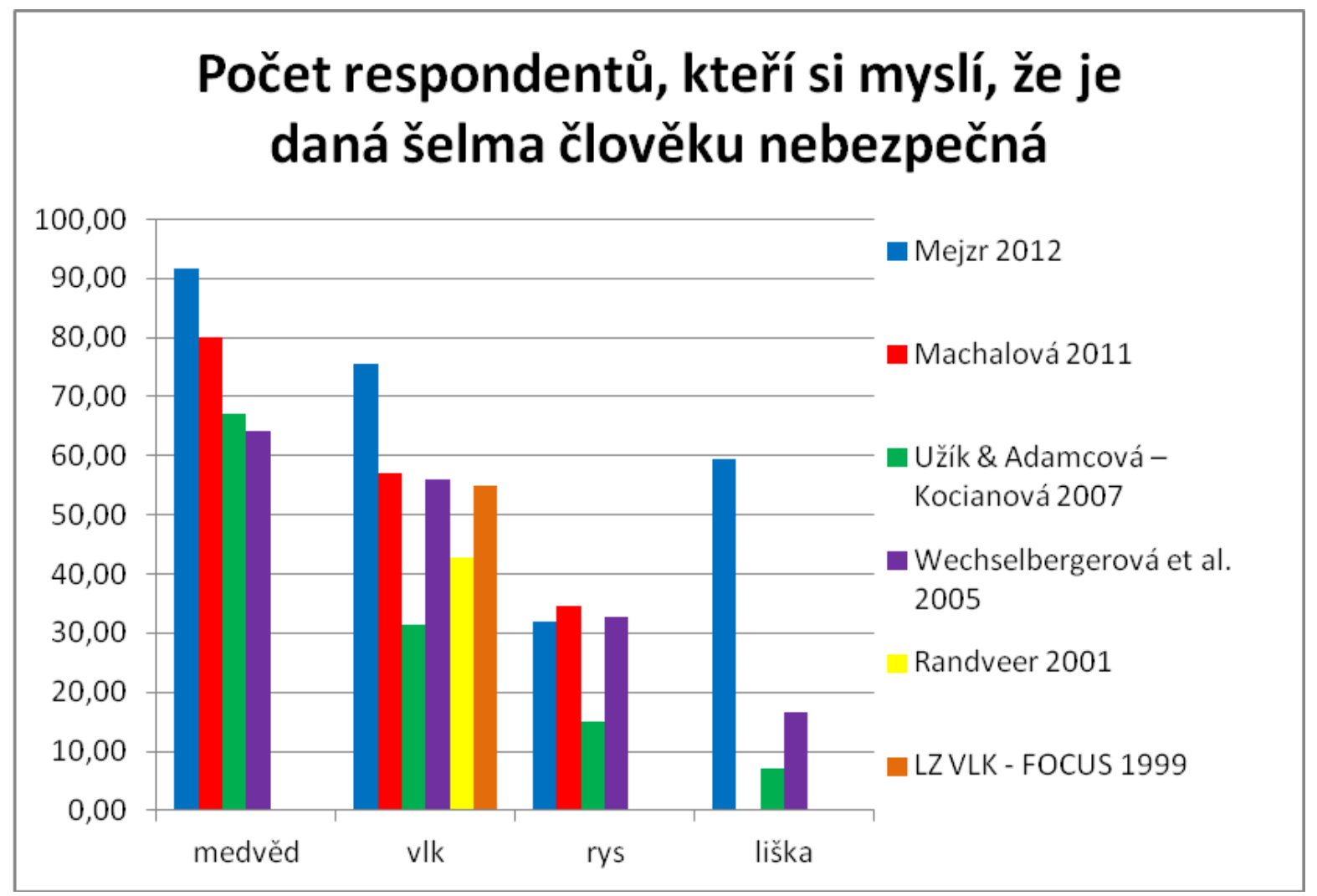

Graf 4: Četnost odpovědí „Ano" u respondentů z různých výzkumů na otázku, zda je daná šelma člověku nebezpečná, v procentech.

Do odpovědí, že na našem území není možné se s vlkem setkat, byly zařazovány i názory žáků, kteří uváděli, že: "spíše ne, jen když se $k$ nám zatoulají ze zahraniči", "vlk u nás není stálý" nebo "v současné době asi ne". Z toho je zřejmé, že i část respondentů, kteří odpověděli, že u nás nemohou potkat vlky, si je vědoma faktu, že se u nás čas od času vyskytují a jejich populace jsou na našem území spíše nestabilní. 


\section{Závěr}

Z provedeného šetření vyplývá, že žáci druhého stupně základních škol jsou o velkých šelmách a jejich případné nebezpečnosti informováni velmi různorodým způsobem. v regionech, kde se šelmy skutečně vyskytují, jsou šelmy přijímány samozřejměji než v regionech jejich výskytu vzdálených. Pozoruhodné výsledky v tomto směru poskytly dotazníky z regionu Beskyd. Potřeba opatrnosti a odpovědnosti, což je primárně nutné zejména při pohybu $v$ regionech pravděpodobného výskytu medvěda a prevence kontaktu s ním, je většině tamních dotázaných známá a patrná. To signalizuje, že výchova $v$ tomto směru, je-li vykonávána, může být úspěšná. Velmi pravděpodobně také úspěšná je. Tento výsledek $v$ době, kdy jsou výsledky dlouhodobého snažení o environmentální výchovu často zpochybňovány, Ize pokládat $v$ jeho podstatě za velmi povzbudivý.

Otázky žákům nebyly kladeny se záměrem zjistit míru takzvaných správných odpovědí. Pokud bychom se zde ovšem snažili dopracovat se kjakýmsi zcela nezpochybnitelným axiomům, museli bychom konstatovat, že míra nebezpečnosti velkých šelem pro člověka je velmi různá. Konflikt člověka a rysa nebyl dosud spolehlivě zaznamenán. Konflikty člověka a vlka jsou sice historicky známé, v posledních 100 letech k nim ale prokazatelně nedošlo. Výjimky z tohoto pravidla mimo jakoukoli pochybnost souvisí s onemocněním vlků vzteklinou, př́padně se zcela nevhodným chováním člověka. Do komplikované situace se může dostat člověk při bezprostředním kontaktu s medvědem. Tyto prípady ovšem zároveň souvisí s dlouhodobým závadným způsobem chování člověka k vlastním nutričním odpadům (tzv. synantropní nebo také kontejneroví medvědi) nebo s pronikáním nezkušených turistů do horských regionů obývaných medvědy (Andreska J., 2010). Nebezpečným se člověku může stát také setkání s medvědicí a jejími mlád’aty. Pokud se člověk vydává do oblastí s výskytem medvědů, měl by se předem seznámit se základními pravidly chování v takovýchto lokalitách (Hnutí Duha, 2012).

\section{Literatura a prameny:}

- Andreska, J. (2010). Velké šelmy jako problém environmentální výchovy (1). Medvěd hnědý.. Biologie, chemie, zeměpis, 19(2), 54-59.

- Andreska, J. (2010). Velké šelmy jako problém environmentální výchovy (2). VIk obecný. Biologie, chemie, zeměpis, 19(3), 106-112.

- Andreska, J. (2010). Velké šelmy jako problém environmentální výchovy (3). Rys ostrovid. Biologie, chemie, zeměpis, 19(4), 158-164.

- Andreska, J. (2012) Škody na rybách v důsledku působení rybožravých predátorů. In Naše rybářství. České Budějovice: Rybářské sdružení České republiky.

- Bath, A. (2000). Human dimensions in wolf management in Savoie and Des Alpes Maritimes, France: Results targeted toward designing a more effective communication campaign and building better public awareness materials. : Memorial University of Newfoundland, Department of Geography. Retrieved http://www.lcie.org/Docs/HD/LCIE\%20Bath\%20Wolves\%20in\%20the\%20French\%20Alps.pd $\underline{f}$

- HNUTÍ DUHA. Šelmy.cz, (2012). Jak se chovat $v$ oblastech s výskytem medvěda. Olomouc: HNUTÍ DUHA. Šelmy.cz. Retrieved from http://www.selmy.cz/medved/jak-se-chovat-voblastech-s-vyskytem-medveda/

- Liukkonen, T., MykrÄ, S., Bisi, J., \& Kurki, S. (2009). Conflicts and compromises in lynx (Lynx lynx) conservation and management in Finland. Wildl. Biol,15(2), 165-174. Retrieved from http://www.bioone.org/doi/abs/10.2981/07-051 http://dx.doi.org/10.2981/07-051

- VIk, L. Z. (2003) Prijatie vel'kých mäsožravcov verejnost'ou. In Pačenovský, S. a G. P. Gadó (Ed.), Priechodné hranice pre vel'ké šelmy (pp. 38-40). Budapest: PRO Vision Stúdió. 
- Machalová, L. (2011). Velké šelmy v CHKO Beskydy z pohledu místních obyvatel a návštěvníků (Diplomová práce). Olomouc: Katedra ekologie a ŽP PřF UP v Olomouci. Retrieved from http://theses.cz/id/zwgvnj/DP Machalova final.pdf

- Mejr, M. (2012). Porovnání postojů žáků ZŠ a SŠ $k$ velkým šelmám, zejména pak $k$ vlku obecnému (Canis lupus) a psu domácímu (Canis lupus familiaris) (Diplomová práce). Praha: Univerzita Karlova v Praze, Pedagogická fakulta, Katedra biologie a environmentální výchovy.

- Randveer, T. (2001). L Lithuania: Siauliai University. Retrieved from http://www.Icie.org/Docs/HD/Randveer\%20wolves\%20in\%20Estonia.pdf

- RØskaft, E., HÄndel, B., \& T. BJERKE a B. P. KALTENBORN, (2007). Human attitudes towards large carnivores in Norway. Wildlife biology, 13, 172-185.

- Užík P. a Adamcová-Kocianová M., (2007) Zistenie mienky verejnosti a navrhnutie manažmentových opatrení pre vel'ké šelmy na Slovensku: An investigation of public attitudes toward slovakian large carnivors and their management proposion in Slovakia. In M. Adamec, P. Urban, \& ADAMCOVA M. (eds (Eds.), Výskum a ochrana cicavcov na Slovensku VIII. Zborník referátov z konferencie (Zvolen 12. - 13. 10. 2007). Banská Bystrica: Štátna ochrana prírody SR.

- Wechselbergová, M., Rigg, R., \& Bětková, S. (2005). An investigation of public opinion about the three species of large carnivores in Slovakia: Brown bear (Ursus arctos), wolf (Canis lupus) and lynx (Lynx lynx). Liptovsky Hradok: SWS.

Ing. Jan Andreska, Ph.D.

Vyučuje na Pedagogické fakultě Univerzity Karlovy. Katedře biologie a environmentálních studií. Specializuje se na vztah člověka a takzvaných problémových živočichů (mimo jiné velkých šelem a ostatních predátorů).

Kontakt: PedF UK, M. D. Rettigové 4, 11639 Praha 1

E-mail: jan.andreska@pedf.cuni.cz

Mgr. Martin Mejzr

Absolvoval navazující magisterské studium na Pedagogické fakultě Univerzity Karlovy v Praze, Učitelství všeobecně vzdělávacích předmětů pro základní školy a střední školy biologie - tělesná výchova

Kontakt: Hrudičkova 2105, 14800 Praha 4;

E-mail: mejzr.m@gmail.com 
Časopis Envigogika vydává Centrum pro otázky životního prostředí UK. Vývoj časopisu je podpořen projektem OP VK Mezioborová sít udržitelného rozvoje.

Více najdete na internetových stránkách projektu http://mosur.czp.cuni.cz
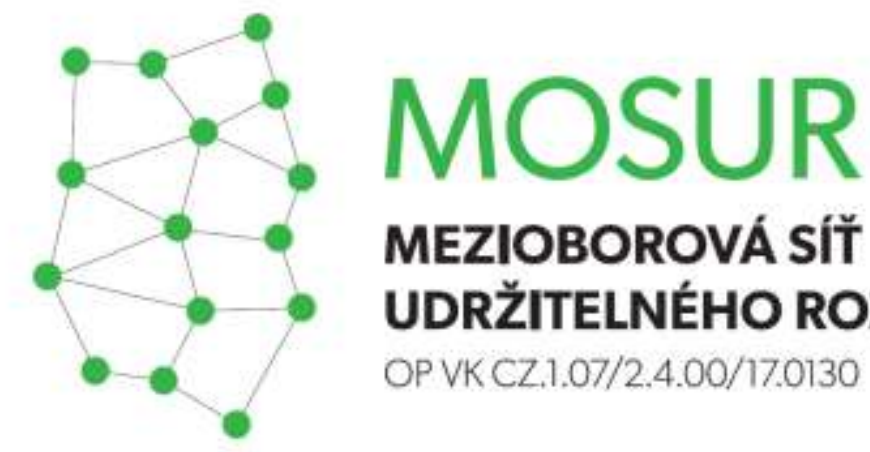

\section{MEZIOBOROVÁ SÍT}

UDRŽITELNÉHO ROZVOJE

OP VKCZ.1.07/2.4.00/17.0130
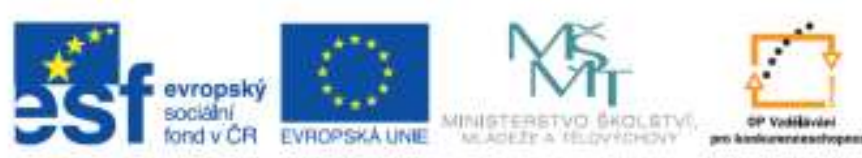

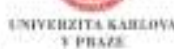

INVESTICE DO ROZVOJE VZDELAVANI 